\title{
Wet Deposition of Heavy Metals in an Arid City
}

\author{
Yuyan Liu' ${ }^{1 *}$ Cheng Liu', Fangfang Tian', Haofeng Liü, Fengshan Shi' \\ 'Department of Chemistry and Applied Chemistry, Changji University, Changji 831100, P. R. China \\ ${ }^{2}$ Changii Environmental Monitoring Station, Changji 831100, P.R. China
}

Received: 24 November 2014

Accepted: 11 January 2015

\begin{abstract}
In order to investigate characteristics of wet deposition of heavy metals in an arid city, precipitation samples were collected for 16 precipitation events in the arid city of Changii. A total of 16 samples were collected and concentrations of principal heavy metals in the atmosphere were examined by inductively coupled plasma-mass spectrometry (ICP-MS) to discuss levels, variation, and wet deposition fluxes of heavy metals. Among these heavy metals in wet deposition, $\mathrm{Fe}, \mathrm{Zn}$, and $\mathrm{Cu}$ were found to be the highest. Levels of As, Ni, and $\mathrm{Cr}$ ranked second, while $\mathrm{Pb}, \mathrm{Cd}$, and $\mathrm{Hg}$ were found to be the lowest. The concentrations of heavy metals in wet deposition showed distinct seasonal variations, having high values in winter and low values in other seasons. Besides, in general, concentrations of heavy metals in snow were higher than those in rain. Because the winter was cold and long in Xinjiang, emissions from coal-fired heating were high, which was associated with enhanced concentrations of heavy metals. The order of wet deposition fluxes of heavy metals in the whole year was $\mathrm{Fe}>\mathrm{Cu}, \mathrm{Zn}>\mathrm{As}, \mathrm{Ni}, \mathrm{Cr}, \mathrm{Pb}>\mathrm{Cd}, \mathrm{Hg}$. Compared to other areas, wet deposition fluxes of heavy metals were low in Changji, which may be due to minimal rainfall in the arid city, having a weak scavenging effect of atmospheric pollutants. In addition, because the level of urbanization and industrialization was not high in Changji, emissions of atmospheric pollutants were low.
\end{abstract}

Keywords: arid city, heavy metals, wet deposition, atmosphere

\section{Introduction}

Particulate Matter (PM) is one of the most important atmospheric pollutants in china. The composition of the particulate pollutants such as heavy metals can cause a lot of diseases, for example, allergies, asthma, and lung cancer. The synergy of PM and heavy metals associated with PM may lead to more severe synergistic toxicological effects. This has increased research interest in heavy metals in the environment over the past few decades around the world. However, information on cleansing mechanisms and the fate of heavy metals is very limited. Atmospheric deposition, which can be in the form of

*e-mail: 824462939@qq.com either dry or wet deposition, is one of the most important pathways for cleansing air of atmospheric heavy metals. Dry and wet deposition can remove heavy metals from the air, which makes concentrations of heavy metals in the atmosphere maintained at a relatively stable level. At the same time, heavy metals can be deposited into surface water and the terrestrial environment, which are associated with adverse human and wildlife health effects $[1,2]$. Migration and transformation of pollutants is unique in arid regions for special meteorological conditions, and studies about cleansing mechanisms and the fate of heavy metals in arid regions are essential [3, 4]. Against this background, research was carried out to determine characteristics of wet deposition of heavy metals in the arid city of Changji. 


\section{Materials and Methods}

\section{Site Selection and Sampling Procedures}

The study was carried out in Changji $(44.05 \mathrm{~N}, 87.31$ E), China, which is in the center of Asia and Europe, and is known as the "Silk Road" of the new North Road. It has a typical continental arid climate. The annual precipitation is only about $200 \mathrm{~mm}$. Precipitation in the form of snow is common during winter and in the form of rain during other seasons. The population of the city is about 420,000 . Due to Western development, Changji has experienced a rapid increase in urbanization in recent years with increased emissions of pollutants and decreased air quality; the urban ecological environment is facing unprecedented pressure.

The sampling sites were established on the Changji College North Campus (Fig. 1). Although the sampling site was in the downtown area of the city, it was more secluded and had less human interference than others in the city [5].

The sampling period was one year (December 2011 through December 2012), and there were 87 precipitation events in total (40 rainy days and 47 snowy days). Based on factors such as precipitation characteristics (precipitation amount, drying time, total precipitation hours, etc.), six snowfall events and 10 rainfall events were selected for samples to be taken (Table 1). The sampling container was a polyethylene bucket; it was washed with dilute nitric acid before precipitation to ensure that each sampling tool was free of pollution, and the container was secured when sampling. After the end of each precipitation, samples were transferred to polyethylene bottles and frozen at $-1{ }^{\circ} \mathrm{C}$. A total of 16 samples were collected. The weather data (temperature, atmospheric pressure, wind speed and direction, and relative humidity) and samples details such as sample quality were recorded and carefully maintained through the study.

\section{Instruments}

The main instruments were as follows: an Agilent ICPMS 7 500Ce inductively coupled plasma mass spectrometer and a Milli-Q water purification system.

\section{Reagents and Standard Solution}

Guaranteed reagent-grade chemicals and ultra-pure water were used for all procedures, unless stated otherwise. Before use, an environmental mixed calibration standard of $\mathrm{Fe}, \mathrm{Zn}, \mathrm{Cu}, \mathrm{As}, \mathrm{Ni}, \mathrm{Cr}, \mathrm{Cd}$, and $\mathrm{Pb}(10 \mu \mathrm{g} / \mathrm{mL}$, Agilent, Part\#5183-4688) had to be diluted to mixed standard solution series $(0,0.5,2,10,50 \mathrm{ng} / \mathrm{mL})$ by stage with $5 \%$ nitric acid (Merck). Standard stock solution of $\mathrm{Hg}(1000 \mu \mathrm{g} / \mathrm{mL}$, Iron and Steel Institute) was diluted to standard solution series $(0,0.5,2,10,50 \mathrm{ng} / \mathrm{mL})$ by stage with $5 \%$ nitric acid (Merck). Mixed internal standard stock solution of ${ }^{6} \mathrm{Li},{ }^{45} \mathrm{Sc}$,

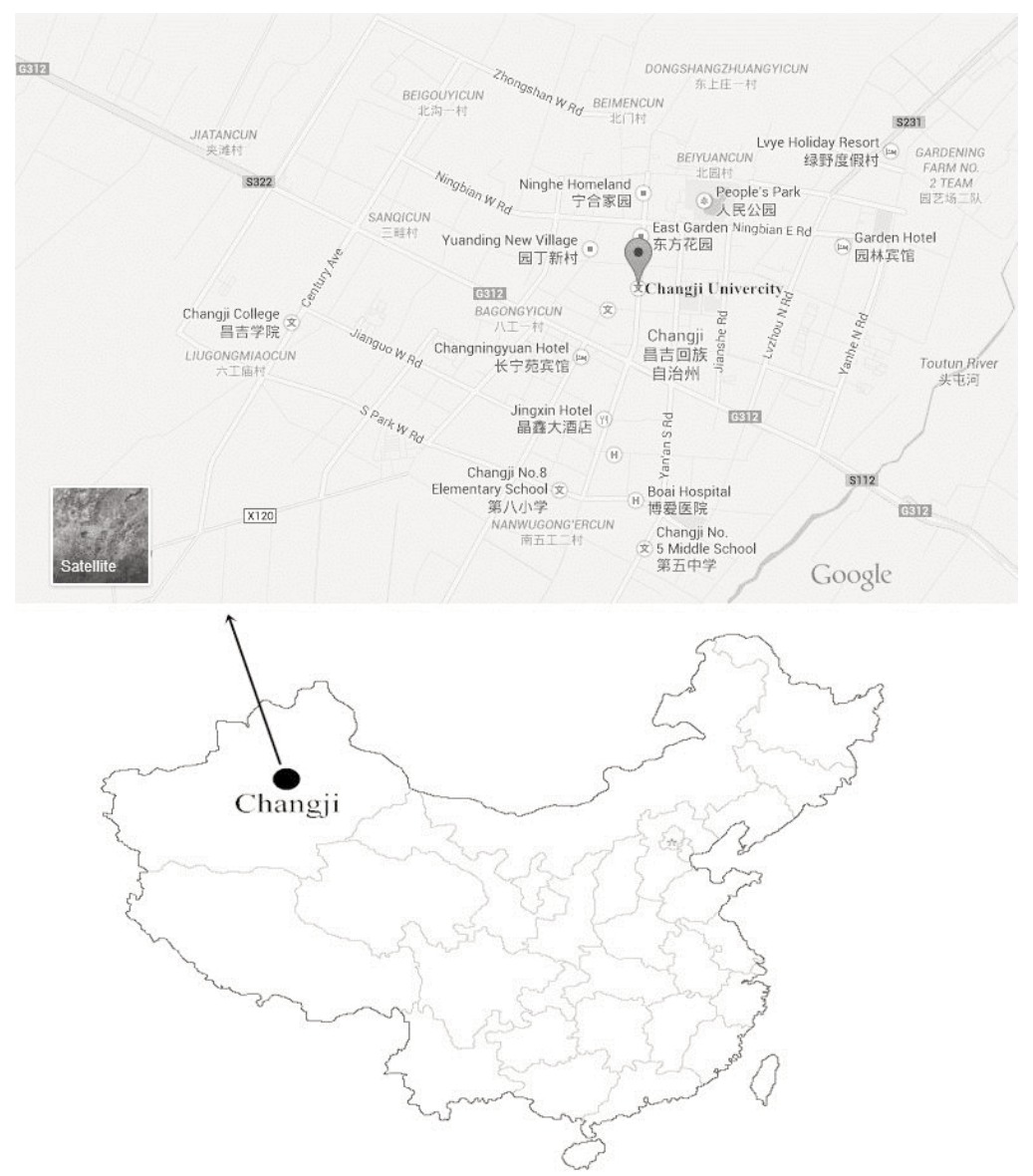

Fig. 1. Map of the study area. 
Table 1 . The concentrations of heavy metals in precipitation for each precipitation event.

\begin{tabular}{|c|c|c|c|c|c|c|c|c|c|c|c|}
\hline \multirow{2}{*}{$\begin{array}{l}\text { Ordinal of } \\
\text { precipitation }\end{array}$} & \multirow{2}{*}{$\begin{array}{c}\text { Precipitation } \\
\text { data }\end{array}$} & \multirow{2}{*}{$\begin{array}{l}\text { Precipitation } \\
\text { form }\end{array}$} & \multicolumn{9}{|c|}{ Concentrations of heavy metals (ng/mL) } \\
\hline & & & $\mathrm{Pb}$ & $\mathrm{Ni}$ & $\mathrm{Cu}$ & $\mathrm{Zn}$ & As & $\mathrm{Cd}$ & $\mathrm{Cr}$ & $\mathrm{Fe}$ & $\mathrm{Hg}$ \\
\hline 1 & $2011-12-31$ & Snow & 1.09 & 3.38 & 8.78 & 7.46 & 6.40 & 0.83 & 1.35 & 104.30 & 0.17 \\
\hline 2 & $2012-12-17$ & Snow & 1.20 & 7.29 & 29.12 & 22.94 & 8.56 & 0.72 & 5.02 & 133.70 & 0.15 \\
\hline 3 & 2012-01-18 & Snow & 0.82 & 16.97 & 82.51 & 111.60 & 2.39 & 0.26 & 2.55 & 56.28 & 0.13 \\
\hline 4 & $2012-02-01$ & Snow & 0.17 & 5.27 & 10.02 & 1.76 & 16.21 & ND & 7.92 & 224.50 & 0.31 \\
\hline 5 & $2012-02-06$ & Snow & 0.98 & 3.09 & 10.99 & 9.77 & 4.48 & 0.31 & 1.33 & 62.88 & 0.13 \\
\hline 6 & 2012-03-07 & Snow & 1.50 & 3.30 & 10.02 & 8.60 & 4.00 & 0.10 & 0.45 & 80.80 & 0.14 \\
\hline 7 & 2012-04-29 & Rain & 0.36 & 1.25 & 9.25 & 9.96 & 3.91 & 0.12 & 3.85 & 71.67 & 0.21 \\
\hline 8 & 2012-05-19 & Rain & 0.36 & 0.38 & 3.05 & 4.55 & 1.04 & 0.08 & 1.37 & 20.51 & 0.16 \\
\hline 9 & $2012-06-03$ & Rain & 0.28 & 1.19 & 4.87 & 5.85 & 2.81 & 0.08 & 1.32 & 65.52 & 0.14 \\
\hline 10 & 2012-06-18 & Rain & 0.09 & 0.46 & 3.03 & 4.71 & 1.85 & 0.06 & 0.67 & 46.38 & 0.10 \\
\hline 11 & 2012-06-22 & Rain & 1.06 & 2.52 & 25.83 & 73.09 & 4.64 & 0.12 & 2.77 & 141.50 & 0.16 \\
\hline 12 & $2012-07-01$ & Rain & 0.15 & 11.90 & 32.59 & 17.31 & 7.66 & 0.11 & 3.40 & 117.60 & 0.23 \\
\hline 13 & 2012-09-15 & Rain & 0.09 & 0.83 & 3.16 & 17.74 & 0.67 & 0.11 & 0.17 & 18.48 & 0.08 \\
\hline 14 & 2012-09-22 & Rain & 0.15 & 1.84 & 8.27 & 20.02 & 1.55 & 0.13 & 0.49 & 27.43 & 0.09 \\
\hline 15 & 2012-10-07 & Rain & 0.09 & 0.40 & 4.57 & 14.69 & 0.39 & 0.09 & 0.14 & 8.73 & 0.08 \\
\hline 16 & 2012-10-19 & Rain & 0.11 & 0.43 & 3.84 & 15.17 & 1.24 & 0.10 & 0.47 & 25.49 & 0.10 \\
\hline \multicolumn{2}{|c|}{ Average } & & 0.53 & 3.78 & 15.62 & 21.58 & 4.26 & 0.21 & 2.08 & 75.36 & 0.15 \\
\hline
\end{tabular}

${ }^{72} \mathrm{Ge},{ }^{89} \mathrm{Y},{ }^{115} \mathrm{In},{ }^{159} \mathrm{~Tb}$, and ${ }^{209} \mathrm{Bi}(10 \mu \mathrm{g} / \mathrm{mL}$, Agilent, part\#5183-4680) was diluted to $1 \mu \mathrm{g} / \mathrm{mL}$ with $5 \%$ nitric acid. Tuning solution was the mixed standard solution of $\mathrm{Li}$, Co, Y, Ce, and Ti (10 ng/mL, Agilent, Part\#5184-3566).

\section{Analysis Procedures}

Samples were removed from the freezer floor and allowed to melt naturally at room temperature. Then the samples were analyzed directly after going through the $0.45 \mu \mathrm{m}$ membrane water.

Under the optimum conditions, blank and standard solution series were collected and the standard curves were automatically drawn by instrument $(r>=0.9999)$. Operating parameters of ICP-MS were automatically defined by the tuning optimization that satisfied sensitivity, background, oxide, dual charge, and stability of equipment installation standards. The main operating parameters of the instrument were as follows: RF power $1450 \mathrm{~W}$, cooling gas 15.0 $\mathrm{L} \cdot \mathrm{min}^{-1}$, auxiliary gas $1.0 \mathrm{~L} \cdot \mathrm{min}^{-1}$, carrier gas $1.06 \mathrm{~L} \cdot \mathrm{min}^{-1}$. The isotopes used in the determination were ${ }^{57} \mathrm{Fe},{ }^{53} \mathrm{Cr},{ }^{60} \mathrm{Ni}$, ${ }^{63} \mathrm{Cu},{ }^{66} \mathrm{Zn},{ }^{75} \mathrm{As},{ }^{111} \mathrm{Cd},{ }^{202} \mathrm{Hg}$, and ${ }^{208} \mathrm{~Pb}$. Based on factors such as mass number of elements, ionization energy of elements, and elemental chemical properties, internal standards were selected. Ge was the internal standard element for $\mathrm{Fe}, \mathrm{Cr}$, $\mathrm{Ni}, \mathrm{Cu}$, and $\mathrm{Zn}$; Y was the internal standard element for As;
In was the internal standard element for $\mathrm{Cd}$; $\mathrm{Bi}$ was the internal standard element for $\mathrm{Hg}$ and $\mathrm{Pb}$. The limits of detection were $2.746 \mathrm{ng} / \mathrm{g}, 0.504 \times 10^{-1} \mathrm{ng} / \mathrm{g}, 0.393 \times 10^{-1}$ $\mathrm{ng} / \mathrm{g}, 1.409 \times 10^{-1} \mathrm{ng} / \mathrm{g}, 0.273 \times 10^{-1} \mathrm{ng} / \mathrm{g}, 2.215 \times 10^{-3} \mathrm{ng} / \mathrm{g}$, $8.132 \times 10^{-3} \mathrm{ng} / \mathrm{g}, 1.038 \times 10^{-3} \mathrm{ng} / \mathrm{g}$, and $7.292 \times 10^{-3} \mathrm{ng} / \mathrm{g}$ for $\mathrm{Fe}, \mathrm{Zn}, \mathrm{Cu}, \mathrm{As}, \mathrm{Ni}, \mathrm{Cr}, \mathrm{Cd}, \mathrm{Pb}$, and $\mathrm{Hg}$, respectively. Their recoveries were more than $85 \%$, and the relative standard deviation was less than $2.5 \%$.

\section{Results and Discussion}

\section{Concentrations of Heavy Metals in Precipitation}

The concentrations of heavy metals in precipitation for all precipitation events are shown in Table 1. Based on concentrations, the elements can be divided into three major groups. $\mathrm{Fe}, \mathrm{Zn}$, and $\mathrm{Cu}$ were found to be the highest, the range of which was $75.36(8.73-224.50) \mathrm{ng} / \mathrm{mL}, 21.58$ $(1.76-111.60) \mathrm{ng} / \mathrm{mL}$, and $15.62(3.03-82.51) \mathrm{ng} / \mathrm{mL}$, respectively. Levels of $\mathrm{As}, \mathrm{Ni}$, and $\mathrm{Cr}$ ranked second, the range of which was $4.26(0.39-16.21) \mathrm{ng} / \mathrm{mL}, 3.79(0.38$ $16.97) \mathrm{ng} / \mathrm{mL}$, and $2.08(0.14-7.92) \mathrm{ng} / \mathrm{mL}$, respectively. $\mathrm{Pb}, \mathrm{Cd}$, and $\mathrm{Hg}$ were found to be the lowest, the range of which was $0.53(0.09-1.50) \mathrm{ng} / \mathrm{mL}, 0.21(0.06-0.83)$ $\mathrm{ng} / \mathrm{mL}$, and $0.15(0.08-0.31) \mathrm{ng} / \mathrm{mL}$, respectively. 

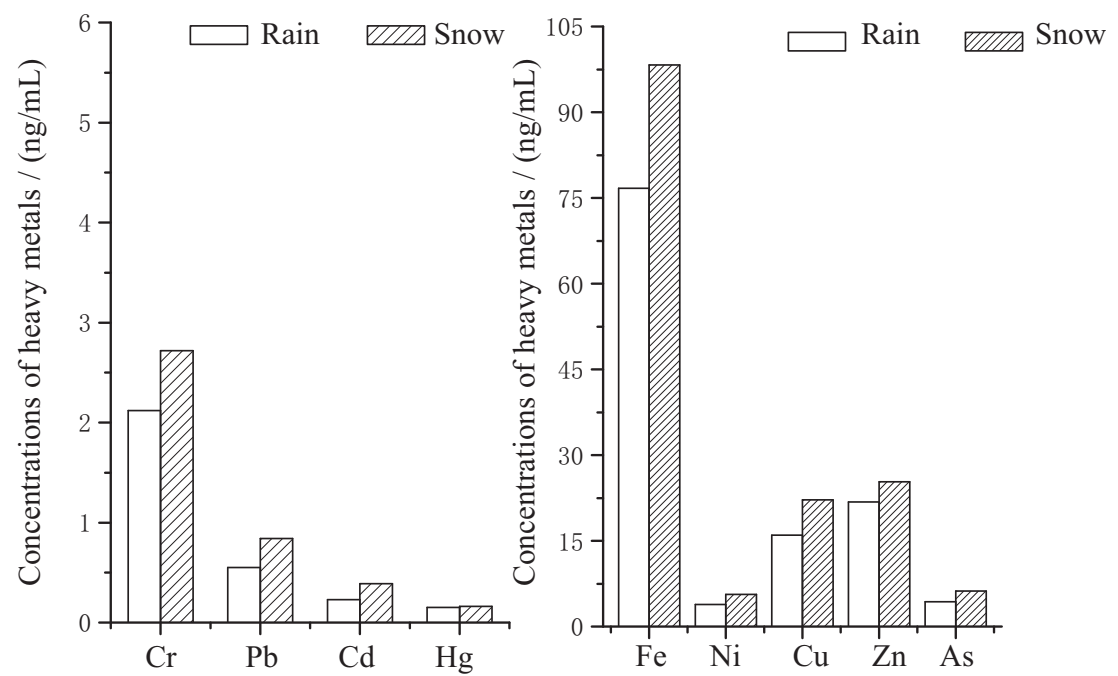

Fig. 2. Concentrations of heavy metals in rain and snow.

\section{Variations on Concentrations of Heavy Metals in Precipitation}

Atmospheric cleansing mechanisms involve wet deposition of atmospheric pollutants in rain and snow forms. In the present study, concentrations of heavy metals in snow generally increasedcompared to those in rain, especially for $\mathrm{Cd}$, $\mathrm{Pb}, \mathrm{Ni}, \mathrm{As}$, and $\mathrm{Cu}$. The higher concentrations of heavy metals in snow were possibly caused by slower fall speeds and higher collection surface area compared with rain. In addition, the crystal shape of snow has been proven to provide an effective filtering effect for aerosols because of their porosity $[6,7]$. The average concentrations of the five heavy metals in rain were $0.23 \mathrm{ng} / \mathrm{mL}, 0.55 \mathrm{ng} / \mathrm{mL}, 3.89 \mathrm{ng} / \mathrm{mL}$, $4.37 \mathrm{ng} / \mathrm{mL}$, and $16.00 \mathrm{ng} / \mathrm{mL}$, respectively. However, those in snow were $0.39 \mathrm{ng} / \mathrm{mL}, 0.84 \mathrm{ng} / \mathrm{mL}, 5.67 \mathrm{ng} / \mathrm{mL}, 6.23$ $\mathrm{ng} / \mathrm{mL}$, and $22.1 \mathrm{ng} / \mathrm{mL}$, respectively, which was about 1.7, $1.5,1.5,1.4$, and 1.4 times higher than those in rain, respec- tively (Fig. 2). The winter was cold and long and the average temperature of the coldest month (January) was about $15.6^{\circ} \mathrm{C}$ in Changji, which made the local heating period last six months. The heating method relied on coal in Changji. There were studies reported that coal contains a lot of heavy metals such as $\mathrm{Cd}, \mathrm{Cr}, \mathrm{As}, \mathrm{Cu}, \mathrm{Pb}, \mathrm{Ni}, \mathrm{Zn}, \mathrm{Fe}$, and $\mathrm{Hg}[8,9]$. Contents of some heavy metals in coal from Xinjiang were higher than the average contents of china and the world [10]. Concentrations of heavy metals in snow were generally higher than those in rain in Changji, which may attribute to large exploitation of coal and rapid urbanization. Because rapid urbanization made the area of the town expand, the area and intensity of heating were increased in winter, which led to increased pollutant emissions making concentrations of some heavy metals in the atmosphere display an increasing trend in winter. A recent study found that particulate $\mathrm{Hg}$ was more effectively scavenged by snow than by rain and low temperature was hardly conducive to volatilization of
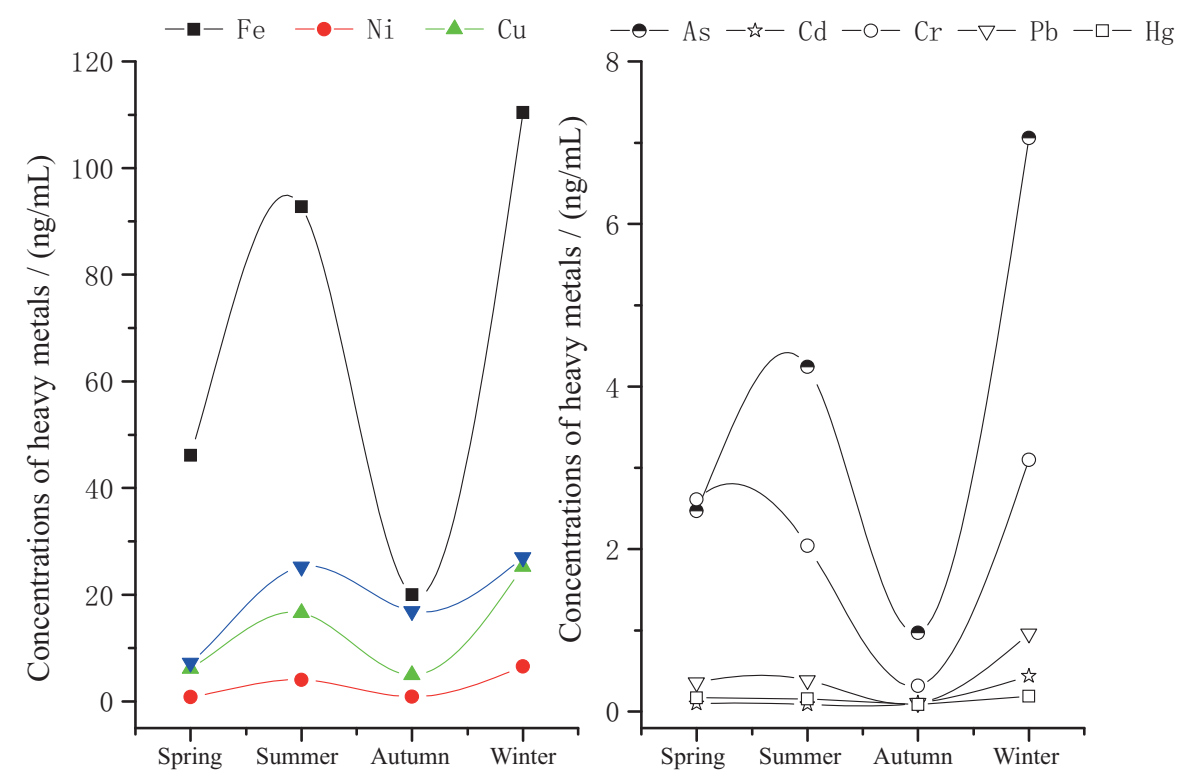

Fig. 3. Seasonal variations of heavy metals in wet precipitation. 
Table 2. Comparison of wet deposition fluxes of heavy metals around the world.

\begin{tabular}{|c|c|c|c|c|c|c|c|c|c|c|}
\hline \multirow{2}{*}{ Location } & \multicolumn{9}{|c|}{ Wet deposition fluxes of heavy metals $\left(\mathrm{mg} / \mathrm{m}^{2} \times \mathrm{a}\right)$} & \multirow{2}{*}{$\begin{array}{c}\text { Data } \\
\text { source }\end{array}$} \\
\hline & $\mathrm{Hg}$ & $\mathrm{Cr}$ & $\mathrm{Cu}$ & $\mathrm{Zn}$ & As & $\mathrm{Pb}$ & $\mathrm{Cd}$ & $\mathrm{Ni}$ & $\mathrm{Fe}$ & \\
\hline Changji & 0.03 & 0.43 & 3.20 & 4.42 & 0.87 & 0.11 & 0.04 & 0.77 & 15.42 & Our study \\
\hline Changchu & 0.02 & 1.70 & 3.74 & 65.78 & 2.13 & 6.82 & 0.21 & - & - & {$[14]$} \\
\hline Xian & 0.05 & 0.71 & 2.11 & 29.53 & 0.57 & 2.40 & 0.14 & 1.01 & - & {$[15]$} \\
\hline Chongqing & - & 2.90 & 13.00 & 76.26 & 4.50 & 30.25 & 0.44 & 2.22 & 73.03 & {$[16]$} \\
\hline Hong Kong & - & - & 4.70 & 33.15 & - & 87.02 & - & - & 67.20 & {$[17]$} \\
\hline Noshiro & - & $0.24-0.61$ & - & - & $0.80-1.60$ & $6.00-12.00$ & $0.19-0.41$ & $0.65-1.07$ & - & {$[18]$} \\
\hline Nakanoto & - & $0.18-0.62$ & $1.40-2.20$ & $19.00-30.00$ & $1.00-2.20$ & $8.00-12.00$ & $0.27-0.35$ & $0.50-2.30$ & - & {$[18]$} \\
\hline Matsuyama & - & $0.27-0.41$ & $0.90-1.60$ & $15.00-29.00$ & $0.79-1.05$ & $6.00-7.80$ & $0.21-0.33$ & $0.73-1.01$ & - & {$[18]$} \\
\hline Tokyo Bay & - & 6.20 & 16.00 & - & 2.90 & 9.90 & 0.40 & 6.80 & - & [19] \\
\hline Izmir & - & $\begin{array}{c}3.41- \\
152.52\end{array}$ & $\begin{array}{c}3.10- \\
866.76\end{array}$ & $\begin{array}{c}54.87- \\
1568.29\end{array}$ & - & - & $\begin{array}{l}0.62- \\
60.45\end{array}$ & $\begin{array}{c}5.58- \\
140.43\end{array}$ & - & [20] \\
\hline Marais-Vernier & 0.01 & - & - & 2.85 & - & 0.10 & 0.01 & 0.32 & - & {$[21]$} \\
\hline Korean countryside & - & - & 1.21 & 6.93 & 0.26 & 1.06 & 0.05 & 0.37 & - & [22] \\
\hline Washington & - & $0.06-4.62$ & - & - & - & $0.11-3.20$ & $0.06-5.10$ & - & - & [23] \\
\hline Recreativo & - & 1.60 & 70.00 & - & 0.60 & 3.40 & 0.10 & 1.40 & - & [24] \\
\hline
\end{tabular}

$\mathrm{Hg}$ in winter, which made relative enrichment of $\mathrm{Hg}$ in snow $[11,12]$. Besides, there was some correlation between the amount of precipitation and the concentrations of heavy metals. Further studies should be performed to determine a better explanation for the problem.

Seasonal variations of heavy metals in wet precipitation were distinct for all of the elements, showing considerably higher concentrations in winter and lower concentrations in other seasons (Fig. 3). Among these heavy metals, seasonal variations of $\mathrm{Cd}$ and $\mathrm{Hg}$ were relatively flat, which may be due to low background value of the environment for these two elements (Fig. 3). The main wet deposition form in winter was snow, which mainly occurred annually from December to the next February, and the main wet deposition form in other seasons was rain. The concentrations of heavy metals in snow were high and concentrations of heavy metals in winter were highest compared to other seasons, which mainly was attributed to emissions of heavy metals from coal-fired heating [13].

\section{Characteristics of Wet Deposition Fluxes of Heavy Metals}

The wet deposition flux of a given heavy metal can be expressed by:

$$
F=C \times P \times 10^{-3}
$$

...where $F$ is wet deposition flux of the given heavy metal $\left(\mathrm{mg} /\left(\mathrm{m}^{2} \times \mathrm{a}\right)\right), C$ is concentration of the given heavy metal in precipitation $\left(\mathrm{mg} / \mathrm{m}^{3}\right)$, and $P$ is annual precipitation amount (mm). Based on average annual precipitation of Changji, $P$ in this study was taken as $204.6 \mathrm{~mm}$.
In our study, wet deposition flux of Fe was 15.42 $\mathrm{mg} /\left(\mathrm{m}^{2} \times \mathrm{a}\right)$, which was found to be the highest among these heavy metals. Wet deposition flux of $\mathrm{Cu}$ and $\mathrm{Pb}$ was 4.42 $\mathrm{mg} /\left(\mathrm{m}^{2} \times \mathrm{a}\right)$ and $3.20 \mathrm{mg} /\left(\mathrm{m}^{2} \times \mathrm{a}\right)$, respectively. Wet deposition flux of $\mathrm{As}, \mathrm{Ni}, \mathrm{Cr}$, and $\mathrm{Pb}$ was small, with a range of $0.87-0.11 \mathrm{mg} /\left(\mathrm{m}^{2} \times \mathrm{a}\right)$. Wet deposition flux of $\mathrm{Cd}$ and $\mathrm{Hg}$ was smallest, with a range of $0.03-0.04 \mathrm{mg} /\left(\mathrm{m}^{2} \times \mathrm{a}\right)$. Some pollutants, even though they exist in the presence of trace or ultra-trace, can seriously threaten human health and the ecosystem, such as $\mathrm{Cd}, \mathrm{Hg}$, and $\mathrm{Pb}$.

The results are further compared with the data from various locations (Table 2). The wet deposition fluxes of $\mathrm{Hg}$, $\mathrm{As}$, and $\mathrm{Cu}$ are comparable to intermediate level and the wet deposition fluxes of $\mathrm{Cr}, \mathrm{Zn}, \mathrm{Pb}, \mathrm{Cd}, \mathrm{Ni}$, and $\mathrm{Fe}$ are lower than average level, which may be attributed to a few precipitation amounts of the arid city, having rare rinsing amounts of atmospheric pollutant. Besides, the small urban population, moderate level of urbanization and industrialization, and relatively little emissions of pollutants may be other reasons. However, as Western development rapidly advances, the rapid growth of the economy may bring unprecedented pressure for the urban ecological environment of Changji, which requires enough attention.

\section{Conclusions}

1. Among heavy metals in wet deposition in this study, concentrations of $\mathrm{Fe}, \mathrm{Zn}$, and $\mathrm{Cu}$ were found to be the highest, and levels of $\mathrm{As}, \mathrm{Ni}$, and $\mathrm{Cr}$ ranked second, while $\mathrm{Pb}, \mathrm{Cd}$, and $\mathrm{Hg}$ were found to be the lowest. 
2. The concentrations of heavy metals in wet deposition showed distinct seasonal variations, having high values in winter and low values in other seasons. Besides, in general concentrations of heavy metals in snow were higher than those in rain. Because the winter was cold and long in Xinjiang, emissions from coal-fired heating was large, which was associated with enhanced concentrations of heavy metals. Meanwhile, $\mathrm{Hg}$ was more effectively scavenged by snow than by rain, and low temperature was hardly conductive to volatilization of $\mathrm{Hg}$ in winter, which made enrichment of $\mathrm{Hg}$ in snow.

3. The order of wet deposition fluxes of heavy metals in the whole year was $\mathrm{Fe}>\mathrm{Cu}, \mathrm{Zn}>\mathrm{As}, \mathrm{Ni}, \mathrm{Cr}, \mathrm{Pb}>\mathrm{Cd}$, and $\mathrm{Hg}$. Compared to other areas, wet deposition fluxes of heavy metals were low in Changji, which may be due to small rainfall in the arid city, having a weak scavenging effect of atmospheric pollutants. In addition, because the level of urbanization and industrialization was not high in Changji, emission of atmospheric pollutants was low.

\section{Acknowledgements}

This research was supported by the National Natural Science Foundation (Nos. 41101497, 41461090), Xinjiang Youth Technological Innovation Projects (2014721009) and Xinjiang Graduate Student Research Innovation Project (XJGRI2014152). The support of the Xinjiang Meteorological Bureau, the Changji city traffic police brigade, and the Changji Clean Sanitation Bureau Group is gratefully acknowledged. The authors thank the Department of Chemistry and Applied Chemistry of Changji University, Tao Gu, Rui Yuan, Shasha Zhang, Chang Gao, Weiwei Zhang, Yao Song, and others in the Department of Chemistry and Applied Chemistry of Changji University for helping us complete the sampling and experimental work.

\section{References}

1. PAN Y.P., WANG Y.S., YANG Y.J., WU D., XIN J.Y., FAN W.Y. Determination of trace metals in atmospheric dry deposition with a heavy matrix of PUF by inductively coupled plasma mass spectroscopy after microwave digestion. Environment Science. 31, 553, 2010.

2. GRANTZ D.A., GAMER J.H.B., JOHNSON D.W. Ecological effects of particulate matter. Environ. Int. 29, 213, 2003.

3. LIU Y.Y., WANG Y.J. Effect of climate conditions in arid area on accumulation of $\mathrm{Pd}, \mathrm{Rh}$ in dust and soil from road environment. China Environment Science. 31, 1528, 2011.

4. LIU Y.Y., TIAN F.F., LIU C. ZHANG L. Platinum group elements in the precipitation of the dry region of Xinjiang and factors affecting their deposition to land: the case of Changii City, China. Atmos. Pollut. Res. 6, (2), 178, 2015.

5. XI D.L., SUN Y.S. Environmental Monitoring; Higher Education Press Publishing: Beijing, pp. 202-204, 2010.
6. TAKAHASHI T. Chemical composition of snow in relation to their crystal shapes. J. Meteorol. Soc. Jpn. 41, 327, 1963.

7. MILLER N.L., WANG P.K. A theoretical determination of the collection rates of aerosol particles by falling ice crystal plates and columns. Atmos. Environ. 25A, 2593, 1991.

8. QI X.X., WANG X.J., LI Y., GUO X.F., WANG J.F. Study on properties of the coal gangues from Xinjiang main coal mine regions and their utilization suggestions. Journal of China Coal Society. 35, 1197, 2010.

9. YANG J.H., ZHANG X.Y. Determination of eleven elements in coal by inductively coupled plasma mass spectrometry. Metallurgical Analysis. 33, 8, 2013.

10. ZHUANG X.G., WANG P., ZHOU J.B., LI J., A M.N. The coal geochemical characteristics of the eastern Junggar coalfield in Junggar Basin, Xinjiang. Xinjiang Geology. 31, 94, 2013.

11. SAINT-LOUIS V.L., RUDD J.W., KELLY C.A. Wet deposition of methyl mercury in Northwestern Ontario compared to other geo-graphic locations. Water Air Soil Poll. 80, 405, 1995.

12. FERRARI C.P., MOREAU A.L., BOUTRON C.F. Clean conditions for the determination of ultra-low levels of mercury in ice and snow samples. Fresen. J. Anal. Chem. 366, 433, 2000.

13. LIU Y.Y., LIU H.F., ZHANG L. The deposition flux of metal elements from snowfall over the arid region in mediumsized and small cities. Environment Monitoring in China. 29, 29, 2013.

14. YANG Z.P., LU W.X., LONG Y.Q., LIU X.R. Current situation of $\mathrm{pH}$ and wet deposition of heavy metals in Precipitation in Changchun City, China. Journal of Jilin University (Earth Science Edition). 39, 887, 2009.

15. YAN X. Pollution characterization of heavy metals in air, soil and precipitation in Xian. Master. Thesis. Xian University of Architecture and Technology, Xian, China. 2013.

16. PENG Y.L., WANG Y.M., QIN C.Q., WANG D.Y. Concentrations and deposition fluxes of heavy metals in precipitation in core urban areas, Chongqing. Environment Science. 35, 2490, 2014

17. ZHENG M., GUO Z.G., FANG M., RAHN K.A., KESTER D.R. Dry and wet deposition of elements in Hong Kong. Mar Chem. 97, 124, 2005.

18. MASAHIRO S., KAZUO A. Factors contributing to seasonal variations in wet deposition fluxes of trace elements at sites along Japan Sea coast. Atmos. Environ. 43, 3867, 2009.

19. SAKATA M., TANI Y., TAKAGI T. Wet and dry deposition fluxes of trace elements in Tokyo Bay. Atmos. Environ. 42, 5913, 2008.

20. AYSEN M., SIBEL C.C. Deposition of heavy metals in a Mediterranean climate area. Atmos. Res. 81, 1, 2006.

21. CONNAN O., MARO D., HÉBERT D., ROUPSARD P., GOUJON R., LETELLIER B., CAVELIER S.L. Wet and dry deposition of particles associated metals $(\mathrm{Cd}, \mathrm{Pb}, \mathrm{Zn}, \mathrm{Ni}$, $\mathrm{Hg}$ ) in a rural wetland site, Marais Vernier, France. Atmos. Environ. 67, 394, 2013.

22. KIM J.E., HAN Y.J., KIM P. R., HOLSEN T.M. Factors influencing atmospheric wet deposition of trace elements in rural Korea. Atmos. Res. 116, 185, 2012.

23. MELAKU S., MORRIS V., RAGHAVAN D., HOSTEN C. Seasonal variation of heavy metals in ambient air and precipitation at a single site in Washington, DC. Environ. Pollut. 155, (1), 88, 2008.

24. CASTILLO S., DE LA ROSA J.D., SÁNCHEZ DE LA CAMPA A.M., GONZÁLEZ-CASTANEDO Y., FERNÁNDEZ-CAMACHO R. Heavy metal deposition fluxes affecting an Atlantic coastal area in the southwest of Spain. Atmos. Environ. 77, 509, 2013. 